\title{
Psychosomatic regularities of psychotic disorders of women in involution (pathogenesis, clinics, psychodynamic psychotherapy)
}

\author{
M. M. Pustovoyt \\ Kyiv Institute of Modern Psychology and Psychotherapy, Ukraine
}

Key words: depressive dis major, narcissistic personality disorder, psychotherapy.

\section{Zaporozhye}

medical journal

2017; 19 (4), 476-481

DOI:

10.14739/2310-1210.

2017.4.105106

E-mail:

pmm2109@gmail.com psychosomatic

The problem of psychotic disorders with onset in the age of involution from broader perspective, guided by modern multidimensional paradigm, was never discussed before. Involutional psychosis is considered as a constellation of the biological changes that are irrefutable in this age period. Certain personality traits and coping strategies can be predisposing to psychotic response, as well as typical features of the "life curve" and external stressors that can run a psychotic reaction. The paper presents the result of our study. This study pays much attention to study of premorbid personality, with emphasis on characteristic features, peculiarities of the emotional reaction and motivation-behavioral area, which completely coincided with characteristics of the narcissistic personality disorder listed in DSM-V (2013).

Aim: To explore the psychosomatic pathogenetic connections inherent involutionary psychosis, given pathogenic and pathoplastic impact of premorbid personality structure their syndromic form and dynamics, determine their place on the psychosomatic continuum and develop adequate and pathogenetic justified method of therapy.

Materials and methods. Data obtained by the clinical method were confirmed by the results of experimental psychological and neuropsychological researches.

Results. Clinical characteristics of psychotic disorders in the patient population showed in the structure of psychosis the existence of two oppositely directed continuums: affective (depressive) and delusional. This allows to allocate four main clinical forms of psychosis and their tendency to unite in two clusters that differed each other by the features, and also by their response to therapy and, therefore, by the prognosis.

Conclusions: The psychodynamic approach to understanding the involutional psychosis, that was introduced by the author, got natural development in the proposed method of treatment that included complex medication and psychotherapy. The schemes of psychotherapeutic influences were developed on the psychotic and post-psychotic stages, higher efficiency of this approach to treatment compared with standard drug treatment schemes was statistically proven. Principal directions of secondary and tertiary psychoprophylaxis and rehabilitation measures aimed at improving quality of life of patients were revealed.

\section{Психосоматичні закономірності психотичних розладів у жінок в інволюції (патогенез, киініка, психодинамічна психотерапія)}

\section{М. М. Пустовойт}

У статті розглянута проблема психотичних розладів в інволюційному віці у ширшій перспективі сучасної багатовимірної парадигми, котра ніколи не обговорювалась раніше. Інволюційний психоз представлений як сукупність біологічних іпсихологічних змін, що є невідворотними в цьому віці. Певні особистісні риси та копінгові стратегії стають сприятливими факторами до психотичної відповіді, відповідальні за характерну «криву життя», а також за сензитивність до зовнішніх стресорів, що провокують психотичну реакцію. У статті представлений результат клініко-психопатологічного та психоаналітичного дослідження цієї проблеми. Велика увага приділяється вивченню преморбідної особистісної структури хворих з акцентом на характерні особливості емоційних реакцій і мотиваційно-поведінкової сфери, які повністю збігаються з критеріями нарцисичного розладу особистості, згідно з DSM-V (2013).

Мета роботи - дослідити психосоматичні патогенетичні зв'язки, що притаманні інволюційним психозам, з урахуванням патогенетичного та патопластичного впливів преморбідної особистісної структури на їхню синдромальну форму й динаміку, визначити їхнє місце на психосоматичному континуумі та розробити адекватну й патогенетично обґрунтовану методику психотерапії.

Матеріали та методи. Дані, що отримали клініко-психопатологічним методом, підтверджені результатами експериментально-психологічних і нейропсихологічних досліджень.

Результати. Клінічні характеристики психотичних розладів у популяції пацієнтів показали наявність двох протилежно спрямованих континуумів у структурі психозу: афективного (депресивного) та маячного. Це дає можливість виділити чотири основні клінічні фрорми психозу та їхню схильність об'єднуватися у два кластери, які відрізняються один від одного психопатологічними ознаками, а також реакцією на терапію і, отже, прогнозом.

Висновки. Психодинамічний підхід до розуміння інволюційного психозу, що введений автором, отримав природний розвиток у запропонованому методі лікування, який включав поєднання медикаментів і психотерапії. Схеми психотерапевтичних алгоритмів розроблені на психотичній і постпсихотичній стадіях захворювання. Вища ефективність цього підходу порівняно зі стандартними схемами медикаментозного лікування статистично доведена. Виявлені основні напрями вторинної та третинної психопрофілактики та реабілітаційні заходи, що спрямовані на поліпшення якості життя пацієнтів. 


\section{Психосоматические закономерности психотических расстройств у женщин в инволюции (патогенез, кииника, психодинамическая психотерапия)}

\section{М. М. Пустовойт}

В статье рассмотрена проблема психотических расстройств в инволюционном возрасте в более широкой перспективе современной многомерной парадигмы, никогда не обсуждаемой ранее. Инволюционный психоз представлен как совокупность биологических и психологических изменений, которые неотвратимы в этом возрасте. Определённые личностные черты и копинговые стратегии становятся предрасполагающими факторами кпсихотическому ответу и ответственны за характерную «кривую жизни», а также за чувствительность к внешним стрессорам, провоцирующим психотическую реакцию. В статье представлен результат клинико-психопатологического и психоаналитического исследования данной проблемы. Большое внимание уделяется изучению преморбидной личностной структуры больных с акцентом на характерные особенности эмоциональных реакций и мотивационно-поведенческой сфреры, которые полностью совпадают с критериями нарциссического расстройства личности, согласно DSM-V (2013).

Цель работы - исследовать психосоматические патогенетические связи, присущие инволюционным психозам, сучётом патогенетического и патопластического влияния преморбидной личностной структуры на их синдромальную форму и динамику, определить их место на психосоматическом континууме и разработать адекватную и патогенетически обоснованную методику психотерапии.

Материалы и методы. Данные, полученные клинико-психопатологическим методом, подтверждены результатами экспериментально-психологических и нейропсихологических исследований.

Результаты. Клинические характеристики психотических расстройств в популяции пациентов показали существование двух противоположно направленных континуумов в структуре психоза: афффективного (депрессивного) и бредового. Это позволяет выделить четыре основные клинические формы психоза и их склонность объединяться в два кластера, которые отличаются друг от друга психопатологическими признаками, а также реакцией на терапию и, следовательно, прогнозом.

Выводы. Психодинамический подход к пониманию инволюционного психоза, введённый автором, получил естественное развитие в предлагаемом методе лечения, включавшем сочетание медикаментов и психотерапии. Схемы психотерапевтических алгоритмов разработаны на психотической и постпсихотической стадиях заболевания. Более высокая эфффективность этого подхода по сравнению со стандартными схемами медикаментозного лечения статистически доказана. Выявлены основные направления вторичной и третичной психопрофилактики и реабилитационные мероприятия, направленные на улучшение качества жизни пациентов.

\section{Introduction}

Modern medicine widely applies the principles of integrative psychosomatic approach to the study of the relationships between the different states of the central nervous system, functional activity of organs and systems as well as individual psychological characteristics [1]. The World Health Organization (WHO) defines the feasibility of this approach and it was confirmed by researches [3].

Psychosomatic and somato-psychic disorders form psychosomatic continuum that reflects the systemic regulation of human life in all its aspects and extends between the poles of physical and mental disorders.

Herewith, the basic pathogenetic mechanism of regulation disorder is based on a circular relationship of psychological, physical and social factors [4].

Consideration of somatic or mental pathology from this perspective calls into question the linear model indivisibility of the structure and function accepted by the medicine [5]. It's focused on a ponderable pathogenetic factor - the personality of a patient, that perceives the change of functions in each moment (or not perceives), responds (or not responds) to a certain behavior (ie, emotions and actions) that eventually leads (or does not) to change of the structure.

Psychiatry compared to general medicine has a deeper understanding of psychosomatic and somato-psychic relations, in particular, it highlights and structures the whole cohort of psychosomatic diseases [6]. At the same time, the existing classification is very general, and it is still rather schematic, insufficiently differentiated for conceptualization a number of transitional forms of varying proportion of pathogenic biological and psychosocial factors.
So many modern biopsychosocial research in psychiatry devoted to the development diathesis-stress model genesis of mental disorders [7] and the concept of psychopathological diathesis within the doctrine of personality disorders $[4,8]$.

Given the abovementioned system-integrative trends in medicine in general and in psychiatry in particular, their rapprochement with psychology, psychoanalytic theory and therapy, as well as insufficient research and implementation of psychosomatic concepts in general medical and psychiatric practices, the development of a system biopsychosocial approach in a field of psychiatry remains relevant as a theoretical and applied problem [9,10].

First of all, it concerns those mental disorders in the etiology and pathogenesis of which can clearly be seen the relationship of biological, individual psychological and social factors, including adjustment disorder with different syndromal structure and psychopathological levels are directly related to such biological and socia-psychological changes in the life of the individual as puberty and menopause [11].

Actually the absence of the integrative model is one of the main reasons for withdrawal of category "Mental disorders involutionary age" from ICD-10 [14].

So, it is still relatively "empty" niche theoretical and applied research in the context of involutional psychosis which can be considered as a holistic integrative psyhosomatic phenomenon and its place among other psychosomatic disorders. This paper shows the results of the study to the development of the said subject.

\section{Materials and methods}

The leading method of our study was clinical psychopathology and additional - experimental-psychological, method
Ключевые слова: психосоматические расстройства, инволюционный психоз, нарциссическое расстройство мичности, психотерапия.

Запорожский медицинский журнал. - 2017. T. 19, № 4(103). C. $476-481$ 
of event-related evoked potentials, statistical analysis of the data.

Experimental-psychological study was performed using the following methods: multi-disciplinary questionnaire of the severity of psychopathology SCL-90-R, Toronto alexithymia scale, the scale of reactive and personal anxiety Spielberger-Hanin, test of actualization of psychological defenses R. Plutcheka, methods of diagnostics of interpersonal relationships $T$. Leary, the questionnaire of the system of individual psychological adaptation and self regulation [12], a clinical questionnaire of personality disorders "IPDE" [13], questionnaire accentuated personality traits LeonhardShmishec, questionnaire "integral index of social well-being" [2]. The method of event-related evoked potentials was to register the electrical activity of the brain in response to auditory stimulus, and also in response to endogenous events related to expectations and identification of significant stimulus in a series of insignificant.

Data Analysis. The statistical analysis of the data was performed using software packages STATISTICA 7.0 and Microsoft EXCEL 2003 with integrated application AtteStat 9.7.1, as well as online calculator SISA (Simple Interactive Statistical Analysis), Internet calculator University of British Columbia (UBC Clinical Significance Calculator), applied methods median test Kraskela-Wallis, Wilcoxon test and Mann-Whitney test, criteria of series Wald-Volfovitsa, test Van der Waerden, applied methods bi-field tables and of variance (ANOVA), and discriminant multivariate analysis.

\section{Results}

The study was conducted at the clinical psychiatric departments of Odessa National Medical University and in the psychoneurological department of Kiev Railway Clinical Hospital № 1. We examined all involutionary patient (age 45-60 years) who were hospitalized to psychiatric hospital for the first time or repeatedly (provided the manifest psychosis after 45 years) with the preliminary diagnosis "involutional psychosis" during a period from January 2003 to December 2007. The patients with severe somatic diseases and endocrine disorders; pronounced cerebral atherosclerosis; the traumas of stroke; severe or repetitive brain injuries in history, were excluded from the study.

As a result, research sample included 234 observations. The control group was formed from anonymous survey results of 47 women of similar age who applied with somatic symptoms to the Kyiv Railway Clinical Hospital № 1 in 2008. The study and interpretation of the data of event-related evoked potentials was conducted with the participation of the Department of Biophysics, Informatics and medical equipment ONMedU (Chair PhD, Prof. L. S. Godlevskiy).

According to the research goal was formulated hypothesis: if personal factor involved in the genesis of IP (involutional psychosis), it is indirectly manifested in actual psychopathological symptoms. In this regard, conducted a detailed clinical analysis of the syndromal structure of IP in the general population with the release of certain types of disorders, patients were examined using the technique "multi-disciplinary questionnaire of the severity of psychopathology SCL-90-R". The regularity of distribution metrics questionnaire in selected types of disorders were studied through the statistical methods. As a result, received arguments in support of the original hypothesis.

Statistical indicators of the distribution of the questionnaire SCL-90-R, according to the discriminant analysis confirmed typological differentiation IP, that was conducted by clinical and psychopathological way. Based on the analysis of clinical manifestations and data SCL-90-R was found a number of symptoms that are common to the entire cohort of patients, and symptoms, which differentiate four clinical forms of IP.

1. Delusional disorders - DD (36 observations, $15.38 \%$ ). Delusive ideas were primary and produced an affective conditions. It was found stable "chronic traumatic factor" in the lives of patients (long family conflict, tensions at work/ residence, forced isolation etc) that almost did not influence on their social activity before the manifest of illness.

2. Hypochondriacal depression - HD (67 observations, $28.63 \%$ ). The thoughts of hard incurable disease gradually acquired the character of possessive hypochondria with a strong sensory component, forming a "crystallization point" of a new "meaning of life" Manifestation of the disorder is often preceded by clearly defined stressful moments in time (leaving the parental home adult children deteriorating relationship with her husband, conflicts at work, etc.).

3. Anxious depression-AD (73 observations, $31.20 \%$ ). On the peak of anxiety and depressive affect can be formed holotymyc delusional experience "guilt" and "punishment", motor excitation was reinforced, which alternated with retardation, motor paralysis with the emotion of fear and despair. Typically developing the disease had traumatic moments in the past (change habitual way of life, painful experience of increasing loss of control over their own lives).

4. Mixed Depressive-Delusional Disorders - MDDD (58 observations, $24.79 \%$ ). Complex interactions between delusive ideas and affect. Psychotic breakdown followed the decline of professional and social status, deterioration of the financial situation.

Among the common features inherent in all types of clinical IP revealed two groups of symptoms:

1) affective disorders - from frustration and relatively small gloom, that is explicable the harassment and persecution, including the poisoning of the inner circle in patients with severe DD; to anguish reaching to anxiety-dreary frenzy in patients with TD;

2) thinking disorders - from overvalued fixation on the unpleasant events of their own health and to clearly expressed delusional ideas with deceptions of perception (often in the form of interpretive illusions), from ideas of sin that are typical for MDDD to clearly defined persekutory delusions of $\mathrm{DD}$. These clinical features were reflected also in the items of SCL-90-R: Depressive and paranoid scales formed two oppositely directed continuums with the highest severity paranoid symptoms and the lowest severity of depressive symptoms in the subgroup DD and the opposite pattern in the subgroup of $A D$.

Tendency to clustering types of IP-based distinct correlation of clinical symptoms of two groups according to the questionaire SCL-90-R results was noticed:

1) somatization - anxiety, which is a cluster combining "DD/HD";

2) introversion - obsession/compulsivity - phobia, which is a cluster combining "MDDD/AD." 
Integrated results for the SCL-90-R in various forms of involutionary psychosis showed the following trends:

1) general index of symptoms severity (GSI) was in all subgroups at a similar level (DD 1.46 $\pm 0.04 ; H D 1.31 \pm 0.03$; MDDD 1.66 $\pm 0.03 ; A D ~ 1.83 \pm 0.02$ );

2 ) the number of answers other than " 0 " (range of psychopathology symptoms - PST), was higher in subgroups MDDD and DD (DD 65.9 \pm 0.8 ; HD $46.01 \pm 0.66$; MDDD $68.16 \pm 0.65 ;$ AD $64.44 \pm 0.71$; ;

3) existing symptomatic distress index (PSDI) was higher in subgroups $\mathrm{HD}$ and $\mathrm{AD}$ (DD 2.03 \pm 0.03 ; $\mathrm{HD} 2.71 \pm 0.01$; MDDD 2.22 $\pm 0.02 ; A D 2.46 \pm 0.02$ ), indicating a higher ability to experience symptoms of "ego-dystoni" and places the disorder on a continuum " pseudo-neurotic-psychotic"

So, at this stage of the study were identified:

1) two oppositely directed psychopathological continuum (depressive and delusional);

2) two clusters of disorders marked by the predominance of one of two pairs of clinical symptoms (somatization - anxiety cluster "DD/HD"; introversion/interpersonal anxiety-obsession-compulsivity-phobia cluster "MDD/AD");

3) psychopathological complexity of DD and MDDD, and bigger "ego-dystoni" - pseudo-neurotic" $H D$ and AD.

The next stage of our study was diagnosis of personality structure of women of study and control groups using a questionnaire accentuation of personality Leonhard-Shmishec, resulting it was found:

1) statistically significant differences between groups on all scales of the questionnaire, excepting for the scale dysthymia that had high rates in both groups;

2 ) the largest scale differentiating role rigidity (DD $17.26 \pm 0.46$; HD 16.54 \pm 0.41 ; MDDD $16.37 \pm 0.47$; AD $15.81 \pm 0.51$ ), significant differential diagnostic value scales of anxiety and hyperthymic;

3) a slight differential diagnostic value of personal attributes dysthymia (DD 11.70 \pm 0.48 ; HD $8.90 \pm 0.55$; MDDD $9.37 \pm 0.54 ; A D 10.43 \pm 0.47)$ and cyclothymia. Thus, the constitutional predisposition to depressive modus of the experience was a determining factor in the formation of $\mathrm{HP}$, including depression forms.

Also, the hypothesis on the probable organic determination of the abovementioned non-specific syndromal personal rigidity, which investigated the state of the auditory analyzer and cognitive function in patients with IP and healthy women of similar age by evoked potentials.

The survey found:

- the differentiation of the representatives experimental group not by the syndromal form of the disorder, but by the age factor;

- constant peripheral conductance, stem, mesencephalic and cortical parts of the auditory analyzer in patients of all ages with no statistically significant difference between experiment and control in the relevant age subgroups;

- no statistically significant differences between the control group and surveyed the parameters latency cognitive evoked potentials characterizing the preservation of cognitive function;

- Instead, decreasing of peak amplitude of P300 in the experimental group as evidence of "burdened" recognition process signals some significant intrapsychological process.

Thus, the study revealed no specific for research group for organic CNS lesions. On the other hand, since the for- mation of the peak P300 cognitive processes associated with the processing of incoming information and general system RAM particular could reduce the amplitude conditional peculiarities of cognitive processes in patients with IP. These features were either the result of the clinical condition of patients, or the expression of personality structure caused by psychological/patopsihologicheskogo factor.

Further research was aimed to identify specific violations in the areas of mental functioning emotions and motivations, psychological defenses, behavior and communication specific to women with IP. To achieve the abovementioned objective questionnaire was used "Toronto alexithymia scale" (TAS) and methods of diagnosis of anxiety R. Charles Spielberger and YL Hanin, the study of psychological defense mechanisms R. Pluchek-G. Kelermana-G. Conte, interpersonal diagnosis T. Leary relations. Analysis of the results of psychometric studies of the individual women with IP found the prevalence syndrome-specific characteristics: high rates of alexithymia, the dominance of immature psychological defense mechanisms (hypercompensation, denial, regression and projection) and a high level of authoritarianism, low level of friendliness and dependence, as well as higher performance altruism in the experimental group compared to the control.

Therefore, the logical continuation of the study was a clinical study of personality of patients with IP and building on the basis of the integrated data model psychopathological personality traits of women with IP. For this representative sample of patients was conducted detailed anamnestic and biographical interviews and psychometric survey using a questionnaire clinical personality disorders IPDE. As a result, synthesis of repetitive patterns of selected leading psychopathological symptoms conventionally delineated them into three discrete groups of characters (in the emotions and motivations, interpersonal relationships and behaviors) and then classified according to modern typologies of personality disorders according to international classification ICD-10 and DSM-V.

As a result of comparison of psychopathological personality traits that were identified among women with IP, typologies of personality disorders, according to international classification ICD-10 and DSM-V, a clear correlation was found for dedicated signs of diagnostic criteria for narcissistic personality disorder. This conclusion is confirmed by the results of a clinical semi-structured interviews personality disorders IPDE (DSM-IV module, block-scale "narcissistic personality disorder") and correlated with the psychometric identified in the study syndrome-nonspecific hypercompensation tendency to involve mechanisms for the settlement / maintaining interpersonal relationships and behavioral rigidity. Thus, two independent ways: clinical and psychometric - found that examples of narcissistic response throughout life is characteristic of women with IP. It was thus confirmed previous assumptions about the availability inherent in all patients, regardless of subtype IP, personality disorder, which is not diagnosed by a test Leonhard-Shmishec.

Analysis of the psychopathological personality traits of studied women and formulation meta characteristics were based on descriptive logic. For the purpose of verification of the results was developed and applied a procedure that allows to check the presence/absence of these psycho- 
pathological symptoms in women in the control group. After that statistical methods were used bi-field tables and ranking personal characteristics from most to least important differential diagnostic. This procedure revealed a clear pattern: the signs of schizoid (combination of autism and emotional vulnerability) most reliably distinguished personality of women with the IP from representatives of control group.

Based on the data were made conceptual conclusions: the compensated narcissistic pathology of personality - is primarily latent pathology/premorbid deficit of psychological mechanisms of individual adaptation and self-regulation; pathology that appears on a phenomenological level, especially in the emotional sphere as the specific features of the individual - undifferentiated emotional sphere, emotional vulnerability and autism. Narcissistic personality pathology that present in surveyed patients, determines the depth of psychological decompensation in involutional age, that is a manifestation of mental disorder. Depth "narcissistic deficit" leads to "pseudo-neurotic" or psychotic forms of mental disorders in involution.

The results allowed to form a scheme of main axises of ratio of personal and syndromic mental pathology in involutionary period of life, which can be seen as from the standpoint of the dynamics of personality disorders with actualization of latent premorbid disease (non-differentiation/ differentiation of emotional sphere), and from the standpoint of comorbidity - the coexistence of two discrete disorders, while personality disorders is promoting the emergence and patho-plastyc "paints" positive psychopathological symptom. This scheme offers opportunities for secondary prevention of IP, can be used for diagnostic purposes to qualify disorder on the basis of "depth narcissistic defect" and will be important for the selecting of the appropriate therapeutic tactics, formulation of a realistic forecast of "recovery" and "restore function", development of ways of tertiary prevention.

\section{Discussion}

Based on proven psychosomatic nature of IP, justified two aspects of psychotherapeutic influence:

1) restore the integrity of the disintegrated system individual-psychological adaptation and self regulation (self) during a psychotic episode;

2) harmonization personal profile, compensation narcissistic deficits in emotional and cognitive spheres through the development of skills of empathy and mentalization in long term.

To achieve these goals during the psychotherapeutic dialogue, it is initiated the construction of understandable for the patient, relations concept between the three basic areas: his personality, "life curve" and actual life situation (including mental illness). The creating of the aforementioned concept occurs if the patient spontaneously actualizes a number of important for himself experiences that are structured as specific topics - the variations of central focus experience.

As a result of using of specialized statistical methods to compare treatment outcomes in patients that were treated with proposed method of psychotherapy (comprehensive treatment) in the study, was found the increasing of the ability of articulation of subjectively meaningful emotional experience; improving the recognition and differentiation of the obtained information; reduce reactive and personal anxiety; easing tensions primitive psychological defense mechanisms and stimulate the development of more mature mechanisms; the transformation of the subjective idea of himself. At the clinical level these effects are manifested in the form of de-actualization of illness experiences, that contributes improve biological and individual psychological elements of adaptation, ensures a long-term compensation of personality structure of patients. For objectification of result, that was obtained, a number of modern statistical indexes of treatment efficacy was used. Abovementioned statistically authentically confirms the effectiveness of proposed algorithm of psychotherapy.

\section{Conclusions}

1. Short-term psychodynamic oriented psychotherapy for patients with IP characterized by accurate phasing, deterministic thematic focus of patient experiences, emotional background, level actualised transfer and suggested interpretive tactics. Subjects of each stage is a partial sub-focus general therapeutic focus, in the current IP therapy: the need for reconciliation with his own life/integration of the system of individual psychological adaptation and self-regulation (self)/ coordination of their own self-concept and concept of the world.

2. Full psychotherapy involves passing a series of phases: the formation of trust in the therapist; expression of claims to entourage ("drainage negative feelings"); memories of their achievements and "good times"; rethinking his life and patient understanding of their personal involvement in it; understanding the connection between their own lives and the relevant disease; excuse themselves for mistakes and finding new values in life.

\section{References}

[1] Uexküll, T., Köhle, K., Herzog, W., Joraschky, P., Kruse, J., Langewitz, W., \& Söllner, W. (2017) Psychosomatische Medizin (1st ed., p. 1264).

[2] Golovakha, E., \& Panin, N. (1989). Psikhologiya chelovecheskogo vzaimoponimaniya [Psychology of the human sympathy]. Kyiv. [in Russian].

[3] (2002). WHO Traditional Medicine Strategy.

[4] Smulevich, A. (2007). Rasstrojstva lichnosti [Personality disorders]. Moscow. [in Russian].

[5] Markov, Y. (1982). Funkcional'nyj podkhod v sovremennom nauchnom poznanii [Functional approach in modern scientific cognition]. Novosibirsk: Nauka. [in Russian].

[6] Tiganov, A. \& Snezhnevskij, D. (1999). Rukovodstvo po psikhiatrii [Manual on psychiatry]. (Vol. 2). Moscow: Medicina. [in Russian].

[7] van der Kolk, B., Pelcovitz, D., Roth, S., Mandel, F., McFarlane, A., \& Herman, J. (1996). Dissociation, somatization, and affect dysregulation the complexity of adaptation of trauma. Am J Psychiatry, 153(7), 83-93. doi: 10.1176/ajp.153.7.83.

[8] Chaban, O., Khaustova, O., \& Zhabenko, O. (2010). Sytuatsiina sotsiokulturalna tryvoha: suchasni provokatsii ta yikh psykhosomatychni rozviazannia [Situational sociocultural anxiety: modern provocation and their psycosomatic solutions]. NeuroNews: psikhonevrologiya neyropsikhiatriya, 4(23), 10-15. [in Ukrainian].

[9] Solms, M. (2011). Neurobiology and the neurological basis of dreaming. Handbook of Clinical Neurology, 98, 519-544. doi: 10.1016/B978-0444-52006-7.00034-4.

[10] Ramachandran, V. (2012). The tell-tale brain. New York: W. W. Norton.

[11] Gureva, V., Dmitrieva, T., \& Makushkin, E., et al. (2007). Klinicheskaya i sudebnaya podrostcovaya psikhiatriya [Clinical and forensic teenager psychiatry]. Moscow. [in Russian].

[12] Deneke, F. \& Hilgenstock, B. (1988). Organisationsformen und Regulationsweisen des Selbstsystems. Zeitschrift Für Psychosomatische Medizin Und Psychoanalyse, 34, 178-195. 
[13] Widiger, T. A., Costa, P. T., McCrae, R. R. (2002) A proposal for Axis II: diagnosing personality disorders using the five factor model. Personality Disorders and the Five Factor Model of Personality. P.T. Costa, T. A. Widiger (Eds). (P. 431-456). Washington, DC: American Psychological Association.

[14] (2010). International Statistical Classification of Diseases and Related Health Problems 10th Revision, WHO, Version 2010.

\section{Information about author:}

Pustovoyt M. M., MD, PhD, DSci, Rector of the Kyiv Institute of Modern Psychology and Psychotherapy, Ukraine.

\section{Відомості про автора:}

Пустовойт М. М., А-р меА. наук, професор, ректор Київського інституту сучасної психології та психотерапії, Україна.

\section{Сведения об авторе:}

Пустовойт М. М., А-р меА. наук, профессор, ректор Киевского университета современной психологии и психотерапии, Украина.

\section{Конфмікт інтересів: віАсутній.}

Conflicts of Interest: author has no conflict of interest to declare.

НаАійшло Ао редакції / Received: 03.04.2017

Після Аоопрацювання / Revised: 18.04.2017

Прийнято Ао Аруку / Accepted: 20.04.2017 